\title{
Nietzsche on 'The Divine'
}

Robin Alice Roth

De Paul University

The problem of "the divine" is a central theme in much of modern philosophy. Like Kant, Hume, and Hegel, Nietzsche accounts for various beliefs within the context of his philosophy, 1.e., the philosophy of Will to Power. Will to Power is all of whatever is. The essence of Will to Power is the will to more and more power. Will to power has no identity; it is not an object, not a substance, and not a thing-in-itself. It simply becomes; it revolves chaotically. Yet "it" does not run off into dispersion and nothingness, for within "its" chaos are qualities binding becoming and restraining chaos, that is, qualities that guide Will to Power's will to (more of) "itself." These qualities measure the differences and likenesses, the strengths and weaknesses between quanta of power. These qualities Nietzsche calls values. Will to Power has no goal, no final state. Man, however, is not identical with Will to Power's chaos. He is unique. He sets goals, for he seeks to order his chaos by giving meaning to his life.

Nietzsche's notion of "the divine" is neither secular nor theological; it is solely philosophical. Reverence is an essential disclosure of man's will(s) to power. Man experiences "the divine" as that which is the most powerful, the mightiest, and the source of human powerfulness and meaning. The mightiest is what Nietzsche means by "the divine." Hence, man needs to experience divinity so as to have a measure to guide his struggle to attain order in life's chaos. For Nietzsche, therefore, "the divine" measures man's strength. The "Greeks used their gods precisely so as to ward off the 'bad conscience', so as to be able to rejoice in their freedom of soul."

The problem is, thus, not that this need should be extinguished. Of course, it can be extinguished. The religious instinct (der religiose Instinkt) may grow or wilt. The Last Man, happy with inertia, laughs at the Madman's cry that "God is Dead." However, the Last Man is the greatest danger to the earth precisely because he will not look beyond himself. Thus, Nietzsche is not arguing that the religious instinct be extinguished, but rather that with the death of the old God, 
the religious instinct be rekindled by a new experience of divinity. Nietzsche has an experience of "the divine, "2 and it is the theoretical explication of this experience which motivates and frames his evaluation of devotedness. Within this evaluation he asks whether the various types of beliefs about God hinder or help man. What do mankind's valuations of godliness mean?

As is well known, Nietzsche delivers a critique of the highest values of mankind. Man, the locus of opposites within will to Power, guides his conflicting will(s) to power by values. Values are man's means for creating order out of chaos and giving himself meaning. Man is both the evaluator and the creator of values. Values set his goals. The highest values in history are to date, moral, and the greater part of morality is robed in sacred attire. This is so even though "in itself, religion has nothing to do with morality." Valuation of "the divine" procribes the goal for "man." However, man has not yet reached his goal; indeed, he is a long way from it. And, in such notions as guilt, these so-called highest, "godly," and moral values have generated the antithesis to man's vitality and fulfillment. For example, the misinterpretation of suffering as guiltiness undermines man's needs to increase power. Again, the belief in another world is supposed to explain the meaning and goal of this life by determining the value of this life according to a better, 'truer' world. In denying value to this life in itself, however, such an answer begs the question of life's meaning; it fails to explain man's earthly sojourn. Since most of religion and morality devalue man's power, most worship and piety signify a loss of vitality for man. Man loses power worshipping a moral view of "God" that opposes human strength. These sacred values are decadent. They dissipate rather than integrate man's power. In answering the question "What for?" through weakness and weariness, Nietzsche calls these values passively nihilistic. They devalue the values of power increment along with whatever is natural, spontaneous, earthly. They over-tame and over-civilize man, suppressing and devitalizing his instincts. This nihilistic scale of values is inadequate to the worth of man's unique destiny. It insufficiently estimates the measure of man's power in relation to divinity.

Knowledge of valuation is the task of Nietzsche's philosophy. In particular, this knowledge of the meaning of sacred values is disclosed through a series of analyses. Each analysis entalls a different kind of nihilism, i.e.. a different style of valuation. Nihilism is the normal condition of man (for man values life, which as a whole cannot be valued). Thus, Nietzsche first gives an elaborate genealogy of religions in general. This uncovers how many interpretations of "the divine" imply passive nihilism, a "decline and recession of the power of the spirit." 
Second, he unfolds a typology of pious personalities. This reveals the multiple interpretations of "the divine" in terms of the genetically created symbols of Theos, and it then ranks these symbols according to instincts. Religious instincts, as the need man has for "the divine," are the conditions for the possibility of interpreting the meaning of divinity. Their ranking is the methodology of active nihilism; Nietzsche's hammer. Finally, through extreme nihilism, a radical revaluation of "the divine" articulates itself in the notion of Overman, Eternal Recurrence, and Dionysus. I shall now discuss briefly each of these analyses.

\section{The Genealogy}

Man experiences divinity by way of his instinctual needs. Within society man internalized his instincts. He thus focused his values away from mastering external life and towards mastering internal life vis-a-vis consciousness. This was a leap. Man went to war with himself. Consciously and unconsciously, he became a collection of confliciting will(s) to power. He sought meaning in a meaningless world. So religion came to fulfill the human need for divine spectators who took great interest in this most interesting animal, man. Put differently, man needed "the divine" both to witness as well as to vindicate the drama of his suffering, his courage, and his struggle for order in the face of a chaotic world. "The divine" fulfilled man's special need for meaning; it expressed his very uniqueness, his created order from chaos.

The existence on earth of an animal soul turned against itself, taking sides against itself, was something so new, profound, unheard of, enigmatic, contradictory, and pregnant with a future that the aspect of the earth was essentially altered. Indeed, divine spectators were needed to do justice to the spectacle that thus began and the end of which is not yet in sight--a spectacle too subtle, too marvelous, too paradoxical to be played senselessly unobserved on some ludicrous planet! "s

Genealogically, Nietzsche shows that man has given various interpretations to "the divine." Eirst, man interprets "the divine" with fear; later "the divine's" presence is felt with ennobling piety during the intermediate stage of the nobles. The nobles understood their gods to be spontaneous, to ward off "bad conscience" and ressentiment, and to justify and make acceptable human life with all its uncertainty. With the victory of the slave Revolt of Morality, however, man perceives "the divine" as the sanctification of 
"mob-ized" morality. Such morality fears man's instincts for freedom, thus, supressing his conflicting will(s) to power and fostering hereditary weakness.

Accordingly, for Nietzsche, this devitalization of the instincts by morality lead to a rigid misinterpretation of "the divine." Sacred values came to express passive nihilism by reducing the conflict and chaos of the world, life, and man to the herd's needs for formation, stabilization, and order."

The genealogy serves as an uncovering of the original upsurge in man's awareness of "the divine," of his experiences of more-than-human power, and the multiple interpretations of these experiences. Yet, Nietzsche distinguishes origin from meaning, arche from telos. The genealogy accounts for what man's needs for divinity have meant in history, and not for the possible value of these needs. The genealogical method, although it sets up the problem of "the divine," is inconclusive. Nietzsche's analysis of the passive nihilism of some venerations and interpretations of "God" is for the sake of a future radical revaluation of man, history, and "the divine." Revaluation, for Nietzsche, means revitalization of man's will(s) to power. Sacred values are no longer meaningful, for "God is dead." An onerous image of "God," such as the Christian conception, has entombed man's goal behind the rock of human inertia. The wonderous-terrible questionability and mystery of existence is diminished; and, the meaning of the symbols through which man interprets "the divine' $s$ " effectiveness in satisfying his needs is eviscerated.

\section{The Typology of Pious Persons}

In contrast to monotheism, Nietzsche demonstrates a plurality of symbols for "God" among differing peoples, times, and individuals throughout history. Entailed in the genealogy is thus an analysis of these peoples and individuals, their spiritual focus and beliefs, and their underlying instincts. This constitutes a typology of pious persons.

Like Xenophanes, Nietzsche, based on his own ontology, poses the problem of the meaning of "the divine" within the framework of a critique of the symbolisms of Theos. The typology of pious persons is the content of this critique. Since God is not a pure "thing-in-itgelf," the symbols for "God" depend on the perspective of the person. God is as He appears to individual men and women; He manifests Himself in idiosyncratic terms. The created meaning is self-referential; man measures his own power correlative to his interpretation of the mightiness of "the divine." "The value-perspective thus disclosed reveals what this type of individual thinks will give his chaos order, is most 
meaningful, is life's purpose, and is the goal for "man."

Reverential and religious instincts are the basis for man's creation of symbols for Theos. These instincts invoke sacrifice and self-overcoming necessitated to increase power. These instincts may be ascending or descending in terms of their quanta of power. Thus, if a man's conflicting instincts increase his quanta of power, his life is ascending, and his will is strong. If, however, his instincts foster hereditary inertia, then his life is descending, and his will is weak. Correlatively, ascending values, in expressing the instincts, both preserve and enhance life; whereas, descending values, in inhibiting the instincts, may preserve but do not enhance life. An example of descending values is the ascetic ideal. The ascetic ideal often serves to protect a degenerating life from its potential to perish. While the ascetic ideal has salvaged man's will from confronting meaninglessness, it has exacted a price for this "salvation"--the devitalization of the instincts. This devitalization of the instincts is the de-deification of man's life. It de-naturalizes and desecrates nature. The ascetic ideal is anti-ascending life; it has given man an inauthentic goal to will. Yet it has been man's only spiritual goal. Thus, the anti-life ascetic ideal has killed God.

Now Nietzsche criticizes not only the ascetic ideal as such, the highest ideal of the moral period, but he also attacks by degrees the various persons and beliefs that exemplify this ideal. Given descending instincts, the variety of interpretations are many; however, the goal is one--to hide chaos unconditionally. Thus, Nietzsche's typology of pious persons is arranged according to instincts (descending or ascending) and evaluated in terms of quanta of power. Power is the criteria; power is the issue.

The typology is as follows:

\section{INSTINCTS PERSONS}

\section{DESCENDING}

Unconditional Jesus

Love

Death, Revenge

ASCENDING

Suffering

Awe

Gratitude

Dionysian Flux

Life
Paul and

Christedom Buddha

Ancient Hebrews Noblemen

Artists

Overman
INTERPRETATIONS OE "THE DIVINE"

Kingdom of God

Otherworld

The Void

Yahweh

Greek Gods

Appearances

Eternal

Recurrence 
This typology accomplishes two things: first, it describes various spiritual beliefs, and second, it evaluates these phenomena in terms of Nietzsche's goal--the enhancement of Will to Power through revaluation. The typology is complex: where there are degrees of strength, as with Jesus, this power is appreciated; where there are degrees of weakness, this impotence is depreciated. This typology is not an argument for a return to polytheism or previous paganism.' But it is an attempt to revalue the reverential and spiritual domain of human existence for the future's sake, for Overman's incarnation.

since the instincts are the ontological conditions for man's life, they constitute the essential subjectmatter of the typographical research which is preparatory for overman. This study is for the few. It requires a new type of discipline--one distinct from the ascetic ideal. It requires active nihilism. ${ }^{\circ}$

Active nihilism holds the means and methods for a new interpretation of "the divine." Active nihilism criticizes values, reverses values, and revalues values. Those values expressing descending instincts and resulting in passive nihilism must be devalued. Nietzsche's philosophy, his hammer, however, destroys in order to create. There are historical examples of sacred symbols which serve as models expressing ascending instincts, for instance, the Greek gods. Such examples show the issue at stake. This issue at stake is a noble use for "the divine" over and against the Christian abuse. Active nihilism creates this higher, nobler ideal. For Nietzsche, this ideal can guide man's will toward a genuinely meaningful future. Active nihilism, active revaluation, in contrast to passive nihilism, reactive devaluation, analyizes human spiritual beliefs in the light of this ideal.

\section{The Revaluation of "The Divine"}

Active nihilism calls for a revaluation of ideals. "Holy lies" are the nomenclature of sacred values, humankind's ideals. The "holy lie" deceives because it forgets or represses some of its conditions. The purpose of the "holy lie" is to make a way of life into. something unconscious, spontaneous, and easy. As such, "holy lies" guide $\operatorname{man}^{\prime} s$ will in a most thorough fashion. In evaluating what is greater and more original than man, the most-powerful, "the divine," "holy lies" symbolize the measure of man. "Holy lies," as ideals, in effect, make man's measure livable.

In discussing "holy lies," what is at stake for Nietzsche is not the will to absolute unconditional truth, the core of the ascetic ideal, which results in atheism. Nietzsche argues against the rigid, moral ascetic ideal. "Religions are destroyed by belief in morality. The Christian moral God is not tenable: 
hence 'atheism'--as if there could be no other kinds of god." 2 Atheism remains as rigid a response to human meaning as Christian morality; both fail to appreciate the flexible essence of Will to Power. Atheism, therefore, is the catastrophe of two thousand years of passive nihilism, especially of Christianity. The passive nihilist, in other words, cannot comprehend the active nihilist's revaluation of "the divine." Thus, in making blatantly atheistic statements, Nietzsche is himself rejecting stagnate symbols for "God" because they are not genuine and godly. Contrary to atheism, for active nihilism, "holy lies" can perfect a type of man through granting him his greatest access to power individually and culturally. Hence, all man's "holy lies" are not to be rejected outright. In part, the problem of the meaning of symbols for Theos is what kind of "holy lie" man should have, what end "holy lies" should serve."

For Nietzsche, bad holy lies use the name of God in vain. "They have killed godliness in and for man. In short, some "holy lies" are bad because they weaken man; however, other "holy 1ies" are good because they strengthen man. "What is good? Everything that heightens the feeling of power in man, the will to power, power itself. What is bad? Everything that is born of weakness." "Nietzsche's criticisms strike at all sacred values templed in bad "holy lies." In turn, -he praises all "holy lies" insofar as they are good and enhance man, preventing him from slipping into inertia and disenchantment with life. Nonetheless, Nietzsche goes beyond praising and blaming. Man is something to be overcome, for man has not brought his chaos into order. Man's meaning is more than man; man's measure is greater than himself. To destroy the anthropomorphic temple of the all-too-human, a new temple, a new "ideal" must be set--overman.

Overman "embodies" an Aufhebung of man and his interpretations of divintiy. Overman redeems the earth from passive nihilism. He is a radicalized appeal for the revitalization of man--man's transformation into the more-than-human. Overman is the earthly measure of man. Being man's measure, Overman may judge all mankind's history as ultimately meaningfui and of worth--1t has all lead to him.

Eor Nietzsche, therefore, active nihilism destroys human inertia in order to prepare for the incarnation of Overman. Active nihilism is the means, but extreme nihilism is the end. Overman practices extreme nihilism. By extreme nihilism, Nietzsche means completion, the culminating point of history which does not terminate in another, better, truer world, but rather in a transformed world. 's This is Overman's world. Overman reinterprets values so that the nothingness and meaninglessness of man's present values are overcome again and again. 
The piety of Overman is Eternal Recurrence. Eternal Recurrence might be called Overman's radically revalued "divine lie." The extreme nihilism of Overman's view of divinity is "iconoclastic" to mankind's senses of "the holy." Thus, Eternal Recurrence, mighty be the holiest of "holy lies," and, consequently, genuinely divine. He who can accept its message declares, "You are a god and never before have I heard anything more divine." By contrast to "the great unholy lie" of Christianity" and its will to nothingness, therefore, the "divine lie" of Eternal Recurrence saves man's will by willing a telos that could be on earth. Accordingly, Overman's revenge-free interpretation of the all-powerful divinity of Dionysus, and of Will to Power as Eternal Recurrence, is Nietzsche's tentative hypothesis for the meaning of "the divine." While himself without goal, Dionysus lets overman enjoy his unique power for evaluation and self-overcoming for goals. In Eternal Recurrence, everything, including man, is eternally reborn, eternally revalued. Nothing is lost. Thus, man need no longer project a short-sighted, linear vision of once-and-forall-ness on life and take revenge against life for death. Dionysus, God of supreme power, says Yes to all of life. He is the divine Yes of everything.

In conclusion, Eternal Recurrence celebrates the victory of the self-overcoming of passive nihilism for the unique project and power of meaning in the abundant omnipotence of Dionysus. Extreme nihilism, what "might be a divine way of thought."1" perceives that all is perspectival. To lie is necessary, for to value is to ile; indeed, to create order out of chaos is to lie. But, this very creation is divine.

\section{NOTES}

'Eriedrich Nietzsche, On the Genealogy of Morals, trans.. Walter Kaufmann (New York: Vintage Books, 1966). II. \#23.

'Eriedrich Nietzsche, The Will to Power, trans.. Walter Kaufmann and R. J. Hollingdale (New York: Vintage Books, 1968), \#1038.

'Nietzsche, The Will to Power, \# 146.

"Nietzsche, The Will to Power, \# 22.

'Nietzsche, On the Genealogy of Morals. II, \# 16.

'Nietzgche, The Will to Power, \# 32 . 
'Nietzsche, The Will to Power, \# 7 .

'Perspective' and 'interpretation' in this context are used synomymously.

'Nietzsche, The Gay Science, trans., Walter Kaufman (New York: Vintage Books, 1974), \#377.

"Friedrich Nietzsche, "The Antichrist" in The Portable Nietzsche, trans., Walter Kaufman (New York: Penguin Books, 1976), \#13.

"Nietzsche, The Will to Power, \# 151.

${ }^{12}$ Nietzsche, Antichrist, \# 56.

1 'Nietzsche, The Will to Power, \# 54.

1"Nietzsche, Antichrist, \# 2 .

18Fiedrich Nietzsche, "The Twilight of the Idols" in The Portable Nietzsche, trans. Walter Kaufmann (New York: Penguin Books, 1976), pp. 485-86.

${ }^{16 N i e t z s c h e, ~ G a y ~ S c i e n c e, ~ \# 341 . ~ N i e t z s c h e ~ s e e m s ~ t o ~}$ make the doctrine of Eternal Recurrence competitive with religion. One could say that in practice Eternal Recurrence has many of the same functions and attributes of some religions, for example, everlasting life. Yet, as a doctrine, Eternal Recurrence is meant to be philosophical.

'Nietzsche, The Will to Power, \#200.

"Nietzsche, The Will to Power, \# 15. 